\title{
Innovation Challenges in Latin American Administration
}

\author{
Paulo Motta and Mariana Bandeira \\ Additional information is available at the end of the chapter \\ http://dx.doi.org/10.5772/intechopen.74736
}

\begin{abstract}
Faced with new challenges, public administration is searching for new levels of responsiveness and efficiency. In most emergent nations, the success of new proposals has been jeopardized by a strong popular distrust in government agencies and actions as well as an era of greater resource scarcity. This chapter deals with some new responses considering the Latin America context. We conducted a documentary survey on public administration responses in Latin America, which allowed to distinguish the possibilities to move toward an ideal of collaborative governance, new public policy values, and public-private partnership, thus reinforcing the arguments about a new logic for thinking about public administration.
\end{abstract}

Keywords: public management reforms, Latin America, post-new public management, collaborative governance, public policy values

\section{Introduction}

By examining the trajectory of public administration, one can clearly see the theoretical and rhetorical movements related with the public and collective spheres, as shown in the bibliography about the search for solutions for public organizations' management problems. Each theoretical movement gathers arguments, experiments, research findings, problems and questions of groups of researchers and is limited to specific realities pertaining to the most relevant problems of an era.

This reinforces the need to understand these movements in a context characterized by elements that are also symbolic, a context which is marked by political disputes while assigning a certain identity to public administration. 
The contemporary perspective on the state-of-the-art in public administration reveals not only a recurrence of themes, dilemmas and paradoxes but also a constant search for relevance and new knowledge to solve practical problems. The historical perspective facilitates understanding the validity and relevance of administrative knowledge because, often, only its application can actually delimit its benefits and downsides. Thus, we can see a history of trials, hits, errors and new approach promises.

After the great revolution of new public management (NPM), with its achievements and mishaps, there have appeared attempts at innovating public management.

The NPM has resumed classical liberalism ideals, particularly the reduction of the state's scope and size and the introduction of market spirit and mechanisms into the government. Thus, public administration should only guide, rather than directly execute services [1]. Citizens should be seen as public service customers and users, rather than mere recipients of the state's action.

Through an intended market-like orientation, the government should play roles that are exclusive to it and unsuitable for execution or control by market mechanisms [2-4].

NPM-associated reforms found enthusiasts [5], severe critics [6], and many analyses of their benefits and negative outcomes [7-9]. Public policies, structures, work processes, and management tools were analyzed, rekindling debates about the limits of administrative theories and practices.

The post-NPM period raised further awareness about the limits of introducing private mechanisms into public management in an effort to recover fundamental values of governmental democracy.

In principle, propositions mimetic of the private sector decreased, whereas those related to the democratic aspects of public service, such as control localization and community participation increased at the bureaucracy level.

Propositions about a new public governance brought about new perspectives on a new role of public management. Initially justified by temporary, isolated reasons, such as addressing economic crises, they gradually revealed their power to become a new reconstruction of public administration more in tune with contemporaneity. Decisions were made toward engaging the civil society and the markets in government while weakening the political aspects of governance [8] in order to find a balance between the interests of all parties involved.

Comparisons between large countries at different stages of development show similar concerns with public management, such as the tendency to view scientific management principles as the axis of their administrative reforms. Today, the concern with government size grows less important in relation to issues such as social performance/care for citizens. Priorities converge to an efficient, transparent, and reliable public management [10]. Despite political differences between countries, there are similar concerns about accountability which are expressed as propositions for restructuring the relationship between public and private and between bureaucracy and citizens [11]. 
In general, propositions on better public governance based on a more authentic relationship between the state and society and between the public and its administration proliferate. For emerging nations, there is an improvement in these relationships, particularly with regard to reliability, participation, transparency, and ethics in management.

By analyzing today's challenges, we resume the main debates about public administration in Latin America in a context in which time dissolves in the movements and in speed. Movementsand here we mean historical movements - mark time periods, spaces and an ethos (being) for public administration, which is being called on to rethink itself using other logics.

We conducted a documentary survey on public administration responses in Latin America, which allowed to distinguish the possibilities to move toward an ideal of collaborative governance, thus reinforcing the arguments about a new logic for thinking about public administration.

\section{Public administration responses in Latin America}

Considering the particularities of the region, Latin America has been organizing to respond in a more solid and effective way to the challenges public administration is faced with.

One such mechanism was the creation, in 1972, of the Latin American Center for Development Administration (CLAD) as a space for discussion, exchange and the fomenting of state modernization. Recognized as an international organization, it has held congresses since 1996 as part of its functioning.

From the general theme of state reform, thematic tracks are defined for each annual congress. For this chapter, our aim was to analyze the priorities discussed in these meetings over the past 10 years.

As a source of data, we used the 73 coordination reports that summarize the presentations in each thematic area, which are available on the CLAD's website. We processed data using the NVivo software to identify the most used terms for each year as well as the ways in which state reform was actually being discussed. The tool allows showing terms in the context they were used in.

As a result, in the following paragraphs, we present a map of the most used terms during the last 10 years (Figure 1).

The terms "public" and "state" were the most cited in the reports during the 10 years studied (2007-2017), followed by "policies," "government," "administration," and so on.

To interpret these terms, we analyzed the cluster chart showing the proximity between the most used terms, as can be seen in Figure 2.

Terms used with some proximity indicate a pattern of connection. In the same cluster, "quality," "innovation," "evaluation," and "results" indicate that these issues were discussed in an interconnected way. Other themes formed a cluster linking "reform," "actors," "society," "civil," and "political." "Citizen," "participation," "open" "government," and "transparency" in "information" are also connected in another cluster. 


\begin{tabular}{|c|c|c|c|c|c|c|c|}
\hline \multirow[t]{3}{*}{ Public } & Policies & Public & Reform & Experiences & services & Quality & Institutional \\
\hline & & \multirow{3}{*}{ Administration } & \multirow{3}{*}{ Process } & \multirow[t]{2}{*}{ Participation } & \multirow[t]{2}{*}{ society } & \multirow[t]{2}{*}{ Subjects } & Model \\
\hline & Government & & & & & & Results \\
\hline \multirow{3}{*}{ State } & & & & \multirow[t]{2}{*}{ International } & \multirow[t]{2}{*}{ systems } & \multirow[t]{2}{*}{ Local } & Transparency \\
\hline & & & & & & & \\
\hline & Management & Social & Developm. & rights & citzenship & Capacity & Innovation \\
\hline
\end{tabular}

Figure 1. Map of the most frequent words at CLAD congresses (2007-2017).

The clusters suggest certain themes in the responses of governments and public administrations in Latin America. The association of terms also reveals how the subject is treated. For example, public served to qualify "function," "administration," "nature," "management," "leadership," "senior management," and "organizations."

We also managed to list these terms by year, thus providing a glance at the priority given to themes at each meeting during the period studied (Table 1).

Thus, one can see the emergence of themes such as "collaboration" - the most frequent in 2017 - and, consequently, of all its correlate terms, which are associated with the involvement of people and institutions, as in collaborative governance.

We can also identify the evolution of certain themes, and how priorities are progressively defined. As an illustration of the latter, we can see that "innovation" appears in 2014 and remains; "ethics" appears in 2009 and 2010 to be replaced by "transparency" (2012 and 2013) and "open" "government" (2014). In 2017, the theme of transparency is resumed.

These meetings' legitimacy provides an integrated view of the trends and responses that are most advocated by Latin American countries. They are quite useful to practical innovation actions and will be explored in the propositions of this study.

\subsection{The present of the past: the permanence of practices inherited from public administration}

By examining the history of the public administration, we can see that the premises of our time remain in many Latin American "public administrations." The models introduced implicitly carried the belief in modern rationality, which is found in advanced nations, as the basis of policy making and public organization. It is worth noting that the efficiency and quality of the services delivered were less supposed to inspire better service standards than to attract political support. This perspective is still consistent with the orientation of the reforms proposed in the region.

As can be seen in the most frequent words shown in Table 1, there are recurrent themes on evaluation, processes, mechanisms, capacities, training, among others, which refer to a modern approach. It was believed-and, in some cases, it still is - that administrative standards 


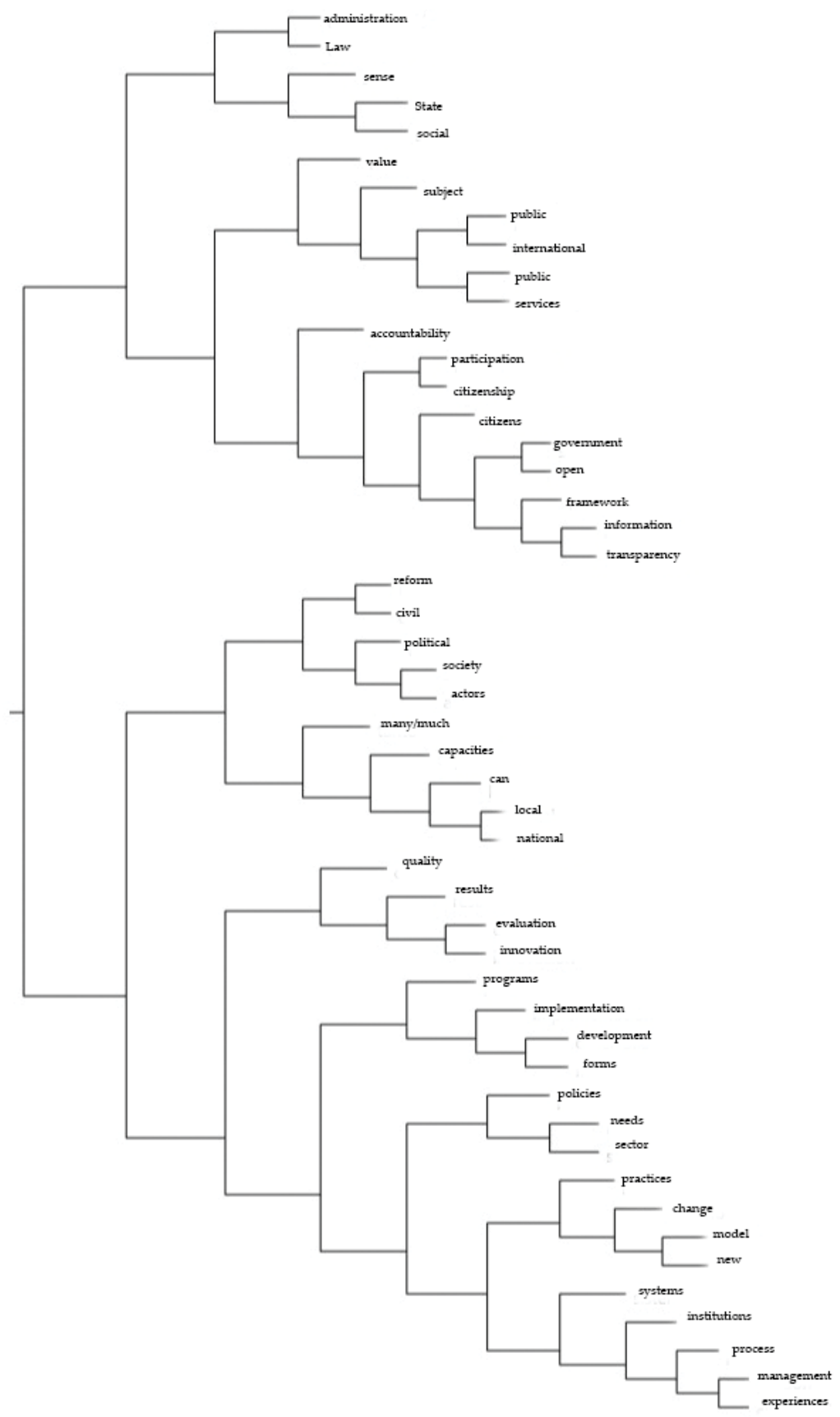

Figure 2. Cluster of most used terms in Spanish-CLAD (2007-2017). 


\begin{tabular}{|c|c|c|c|}
\hline Year & Over 100 times & From 51 to 99 times & From 30 to 50 times \\
\hline 2007 & $\begin{array}{l}\text { Public, state } \\
\text { government }\end{array}$ & Policies, social, management & $\begin{array}{l}\text { Development, administration, public, } \\
\text { processes, society, international, formation, } \\
\text { reform, function }\end{array}$ \\
\hline 2008 & Public, policies & $\begin{array}{l}\text { State, management, reform, } \\
\text { administration, society, quality, } \\
\text { public, political, social }\end{array}$ & $\begin{array}{l}\text { Civil, development, international, processes, } \\
\text { government, capacities, experiences, } \\
\text { participation, local, personnel, programs, } \\
\text { thematic, relation }\end{array}$ \\
\hline 2009 & Public & $\begin{array}{l}\text { State, policies, management, } \\
\text { public, administration }\end{array}$ & $\begin{array}{l}\text { Government, results, international, reform, } \\
\text { ethics, social, society, experiences }\end{array}$ \\
\hline 2010 & Public, government & $\begin{array}{l}\text { Policies, state, management, } \\
\text { administration }\end{array}$ & $\begin{array}{l}\text { Citizen, ethics, systems, processes, public, } \\
\text { reform, participation, social, service, } \\
\text { experiences }\end{array}$ \\
\hline 2011 & Public & $\begin{array}{l}\text { Policies, government, state, } \\
\text { management }\end{array}$ & $\begin{array}{l}\text { Administration, systems, social rights, } \\
\text { experiences, evaluation, participation, } \\
\text { processes, information, public, mechanisms }\end{array}$ \\
\hline 2012 & Public, state & $\begin{array}{l}\text { Administration, right, public, } \\
\text { government, policies, reform }\end{array}$ & $\begin{array}{l}\text { Participation, accounts, citizens, management, } \\
\text { social, information, international, processes, } \\
\text { transparency, general }\end{array}$ \\
\hline 2013 & $\begin{array}{l}\text { Public, government, } \\
\text { administration, social }\end{array}$ & $\begin{array}{l}\text { State, policies, locations, open, } \\
\text { participation, public, process, } \\
\text { information, management, rights, } \\
\text { development, reform, experience }\end{array}$ & $\begin{array}{l}\text { Society, services, international, citizens, } \\
\text { decentralization, model, systems, access, } \\
\text { countries, transparency, region, capabilities, } \\
\text { spaces, political }\end{array}$ \\
\hline 2014 & $\begin{array}{l}\text { Public, state, } \\
\text { government, } \\
\text { management }\end{array}$ & $\begin{array}{l}\text { Experience, administration, } \\
\text { policies, public, processes, social } \\
\text { rights, participation }\end{array}$ & $\begin{array}{l}\text { Open, thematic, international, reform, } \\
\text { rights, decentralization, services, countries, } \\
\text { innovation, development, institutions, local, } \\
\text { quality, systems }\end{array}$ \\
\hline 2015 & $\begin{array}{l}\text { Public, government, } \\
\text { administration }\end{array}$ & $\begin{array}{l}\text { State, policies, public, open, } \\
\text { social, management, rights, } \\
\text { participation, processes, } \\
\text { development, reform, service, } \\
\text { citizen, local }\end{array}$ & $\begin{array}{l}\text { International, cities, experiences, thematic, } \\
\text { quality, civil, implementation, innovation, } \\
\text { decentralization, institutional, countries }\end{array}$ \\
\hline 2016 & $\begin{array}{l}\text { Public, policies, } \\
\text { administration }\end{array}$ & $\begin{array}{l}\text { Management, government, } \\
\text { evaluation, innovation, } \\
\text { reform, social, right, process, } \\
\text { development }\end{array}$ & $\begin{array}{l}\text { International, system, citizens, experiences, } \\
\text { service, participation, design, need, } \\
\text { implementation, change, industry, thematic, } \\
\text { new, problems, work, practices, countries, } \\
\text { tools, matter, model }\end{array}$ \\
\hline 2017 & Public, administration & $\begin{array}{l}\text { Development, management, } \\
\text { state, policies, goals, sustainable } \\
\text { development, social }\end{array}$ & $\begin{array}{l}\text { Evaluation, reform, government, } \\
\text { experiences, international, law, institutions, } \\
\text { innovation, agenda, transparency, } \\
\text { services, implementation, models, citizens, } \\
\text { collaboration, processes, society, thematic, } \\
\text { value, capacities }\end{array}$ \\
\hline
\end{tabular}

Source: NVivo 11 Output, elaborated based on CLAD 2018 area reports.

Table 1. Most frequent words in clad reports - by year.

could actually enhance public management efficiency and, therefore, solve social and economic problems, and, most of all, break with the political influence of traditional political groups. 
It is worth mentioning important political and social achievements under the name of "participation," "citizenship," "rights," "actors." However, in most countries, the reality reflects the domination of traditional oligarchies. Effectiveness and efficiency gains remain as speech in support of the preferential groups in power. Therefore, despite the achievements mentioned, state modernization remains under strong influence of traditional practices.

\subsection{The present of the present: shared experiences}

In fact, the experience of recent times has been less useful for achieving greater effectiveness in public administration than for introducing new groups into the "clan" system. It also revealed administrative modernity as a supplier of more efficient tools for traditional power groups to ensure their own permanence. Knowledge, new models, and administrative practices proved insufficient to substantially change the state-society relationship. This argument is illustrated in the way more substantive issues are so much less frequent than the exchange of experiences related to management and administration mechanisms in the public sphere.

In most Latin American nations, because of its fragile foundations in society, the state becomes an easy prey to traditional groups tied to their own interests. In a way, political-administrative institutions float above the society. Formally, the laws and rules of democracy have progressed in most countries in the region. But the political system still suffers from the poor education of a significant part of the population, which results in subservience to populist, self-interested movements.

Thus, advanced propositions of change fail to reach deep enough into the power relations manifested in the political sphere, besides lacking space in the agenda of discussions.

\subsection{The present of the future: projections and hopes based on trends}

In developing countries, modernizing political forces do not come to power by a voluntary retraction on the side of preferential groups. New spaces, rules, and political structures are required to distribute power resources and ensure the representation of new, emerging social groups. Thus, concerns emerge about the following question: which modern, post-managerial administration propositions could actually contribute to improve state-society ties?

Effective modernization must come in ways that can redistribute power resources and change the communication channels between the public and its administration in order to contribute to the sustainability of effective management.

We can project, based on the themes most frequently mentioned at last year's CLAD Congress, that the agenda is focused on sustainability, development, achievement of goals, social inclusion, necessity of evaluation, collaboration, value creation and capacity building, transparency, and international perspectives.

Each proposition contributes to modernization, and each has successful cases. However, democratic learning, even at the level of public management, was deemed an important foundation for progress. Thus, recent, widely diffused ideas about collaborative governance were given a greater weight. However, adjustments are required on their implementation in the Latin American context. 
Collaborative governance propositions advocate participation because they assume interests to be convergent. Indeed, in more advanced countries, state-society relations are already founded on democratic principles and practices. Exercising democracy in public governance means an extension of an already established practice for the administrative sphere.

In emerging countries, social exclusion, the dominance of preferential groups and the illegitimacy (and perception thereof) of electoral processes give the decision-making process political characteristics - which are highly conflictive and divergence-centered, therefore commonly portrayed as irreconcilable.

In this context, participatory processes are usually portrayed as useful not only for political decision-making, but also for the democratic education of the individuals involved.

The results of our survey show a heavy presence of participatory themes, such as citizen participation and open government. In fact, they are attractive subjects as they represent a compensation for participatory constraints in the larger democratic context.

Participation as a governance tool dates to decades ago, including in the private sector, with European legislation that dealt with different forms of co-management. Initially, they valued participation on the assumption of divergent and conflicting interests, which established alliances by engaging actors previously considered as marginalized social groups. Therefore, in the Latin American context, the term participatory appears more often than the term collaborative.

\subsection{Timeless reflections: transitions or reiterations?}

Some of the Latin American responses in public administration during the period analyzed seem to appear repeatedly, while others point to the possibility of developing propositions from another perspective.

Reiterations are probably necessary to explore propositions' possibilities, achievements and failures. However, they express a problem that still lacks a consolidated solution. Among those, the issues of transparency (and derivations thereof, such as corruption, ethics, responsibility), participation and decentralization still find space in the public agenda of Latin American countries.

Public administration's inefficiency and unresponsiveness have led to dangerously high levels of distrust in the public sector's institutional capacity. The government faces distrust in its administrative and legal apparatuses, viewed as distant, inaccessible, inefficient and disinterested in community well-being.

Currently, in many countries, dubious/proven corrupt actions seem to reveal the need to strengthen ethical and moral standards in administrative decisions and actions. Ethics appears in all propositions as an essential mechanism for restoring trust in the public sphere. Greater attention to the personal integrity of public administrators and the strengthening of laws to deal with the lack of ethics are advocated.

In the contemporary context, characterized by strong ambiguities, there is a complexity of rules, traditions and interactive practices capable of restricting, obscuring and disguising 
people's moral and ethical conceptions. Thus, there are limits to the proposition of bills on integrity. On the one hand, even for people defined as honest, temptations can cause slips; on the other hand, laws and rules do not inhibit illegality, and their meaning is less about building good (an ideal state) than avoiding evils.

Therefore, propositions of administrative tools and new managerial practices emerge as facilitators of ethical actions. Among such propositions, participation and transparency stand out.

On the other hand, collaborative governance emerges as a possibility to change mindsets and is further strengthened by the current, timely context of re-institutionalization in Latin American governance.

As a forum for debating public administration policies and practices, collaborative governance has been proposed in recent years as a public- and private-sector governance strategy in which both parties work toward the provision of public goods [12].

From the perspective of collaborative governance, there is always a fundamental concern with balancing the power of both participants/actors and authority structures. Here, the distribution of opinion and decision-making power among participants of different hierarchical levels stands out. Among the benefits of collaborative processes, it is worth highlighting an increase in the following: decision legitimacy; ability to respond to complex situations; and effectiveness and flexibility [13].

On the other hand, this transition is not carried out at once as it requires a change in the way of understanding what role each actor should play. Rethinking roles and responsibilities implies a new culture of relations between government, businesses and civil society [14], each of these autonomously exercising its rights and fulfilling its duties.

Although it is true that engaging a great number of actors produces more alternatives and results for public policy, such results are moderated by the personal/organizational interests of these actors [15], who could confront collective interests and needs.

Collaborative governance also encompasses dimensions that are sometimes neglected, such as the various institutional jurisdictions of public policies and the multiplicity of interpretations found in the process, as well as the engagement of socio-productive networks in the decision-making process [16].

The natural complexity of adopting this new stance in public management requires some additional efforts, as identified in the following sections.

\subsection{Guidelines for collaborative governance}

Perhaps the most critical aspect to building collaborative governance is the balance between the various forces operating in public management [17]. It is also worth remembering that individual values are often prioritized to the detriment of collective ones [15], and reversing this ethical stance demands an additional effort from managers. Some authors believe that managers have an important role in this context, as there is the belief that intentionally using collaborative strategies can circumvent structural barriers and optimally reduce institutional obstacles [18]. 
Moreover, it is necessary to promote the balancing and distribution of the power of participants/actors and authority structures, with an emphasis on the opinion and decision-making abilities of the different hierarchical levels and actors. Involving more representatives can not only benefit the ability to respond more effectively to complex situations, but also reinforce the legitimacy of public decisions [13].

Promoting an ethical-political culture with a collective focus could facilitate this integration between actors. In this respect, awareness should be raised about the personal/institutional interests of the represented, as well as the possibility of moderation by a great number of actors and more alternatives and results for public policy [15]. Diversity should be seen as a benefit and a learning opportunity in this context [19].

In addition, although the subject of participation and citizenship is widely discussed, it is still important to reinforce the debates and practices of public administration with an effective partnership in the making of public and regulatory policies [12, 20]. Recent research fuels this proposition, recognizing collaborative networks' difficulties regarding establishment and interaction. In highly collaborative environments, one can see more concentrated interactions and more constant communication, including a balance of forces, which turns out to be different in noncollaborative environments. This result shows the complexity of collaborative governance in political networks, where a balance must be sought between aspects such as agreements, time and institutional boundaries [21].

The aim of considering the multiplicity of interpretations and different institutional jurisdictions of public policies and socio-productive networks is to help improve decision-making processes [16]. The search for innovation in public management also requires managers to know the relevant legal framework and to be able to solve the contradictions between the different regulatory frameworks in effect [22]. The dialog between policy, management, and regulation should be permanent.

Finally, the adoption of steering committees can help the interactions between partners by addressing unanticipated contingencies and mitigating incipient ones when there is a strong need for coordinated adaptation [23].

\section{Final considerations}

This chapter focuses on the challenges of moving toward a collaborative governance management model in the context of a developing nation. The framework of our analysis consists of two dimensions. The first examines the past trajectory of public administration, using a metaphor of time. The second involves a documentary survey on the most discussed subjects at the CLAD (Latin American Center for Development Administration) Congresses on State Reform in the last 10 years.

In order to face the complexities of today's scenario, governments have invested in a new strategy that promotes co-participation, co-responsibility, and collaboration, as well as a new culture of relations between the business community, civil society organizations and public institutions. Collaborative governance has emerged as a dimension of probable effectiveness for public management. 


\section{Author details}

Paulo Motta ${ }^{1 *}$ and Mariana Bandeira ${ }^{2,3}$

*Address all correspondence to: paulo.motta@fgv.br

1 Brazilian School of Public and Business Administration at the Getúlio Vargas Foundation (EBAPE-FGV), Rio de Janeiro, Brazil

2 Simon Bolivar Andean University (UASB), Quito, Ecuador

3 Milagro State University (UNEMI), Milagro, Ecuador

\section{References}

[1] Osborne D, Gaebler T. Reinventando o Governo: Como o espírito empreendedor está transformando o setor público. 6th ed. MH Comunicação: Brasília; 1995. 436 p. ISBN: 9788585660017

[2] Osborne S. The (new) public governance: A suitable case for treatment? In: Osborne S, editor. The New Public Governance? Emerging Perspectives on the Theory and Practice of Public Governance. London: Routledge, 2010. pp. 1-16. ISBN: 9780415494632

[3] Denhardt JV, Denhardt RB. The New Public Service: Serving not Steering. New York: M.E. Sharpe; 2007. 240 p. ISBN: 978-0-7656-1998-3

[4] Kettl DF. The Global Public Management Revolution: A Report on the Transformation of Governance. Washington DC: The Brookings Institution Press; 2005. 96 p. ISBN: 0815749171

[5] Hughes OE. Public Management and Administration: An Introduction. 3rd ed. Basingstoke: Palgrave Macmillan; 2003. 336 p. ISBN: 0-333-96188-9

[6] Flynn N. Public Sector Management. 6th ed. London: Sage; 2012. 296 p. ISBN (Pb): 978-0-85702-874-7

[7] Pollit C, Bouckaert G. Public Management Reform: A Comparative Analysis. Oxford: Oxford University Press; 2004. 360 p. ISBN: 9780199268498

[8] Peters BG. Meta-governance and public management. In: Osborne S. (Ed.) The New Public Governance? Emerging Perspectives on the Theory and Practice of Public Governance. London: Routledge; 2010. pp. 36-51. ISBN: 9780415494632

[9] Christensen T, Laegreid P. Transcending New Public Management: The Transformation of Public Sector Reforms. Hampshire: Ashgate; 2007. 288 p. ISBN (Pb): 978-0-754-67117-6

[10] Zhang M. Crossing the river by touching stones: A comparative study of administrative reforms in China and the United States. Public Administration Review. 2009;69(S1, special number):S82-S87. DOI: 10.1111/j.1540-6210.2009.02093.x

[11] Zhao Y, Peters BG. The State of the State: Comparing governance in China and the United States. Public Administration Review. 2009;69(S1, special number):122-128. DOI: 10.1111/j.1540-6210.2009.02099.x 
[12] Ansell C, Gash A. Collaborative governance in theory and practice. Journal of Public Administration Research and Theory. 2007;18:543-571. DOI: 10.1093/jopart/mum032: 10.1093/jopart/mum032

[13] Purdy JM. A framework for assessing power in collaborative governance processes. Public Administration Review. 2012;72:409-447. DOI: 10.1111/j.1540-6210.2011.02525.x

[14] Abony G, Van Slyke DM. Governing on the edges: Globalization of production and the challenge to public administration in the twenty-first century. Public Administration Review. 2010;70:33-45. DOI: 10.1111/j.1540-6210.2010.02244.x

[15] Siddiki SN, Carboni JL, Koski C, Sadiq AA. How policy rules shape the structure and performance of collaborative governance arrangements. Public Administration Review. 2015;75:536-547. DOI: 10.1111/puar.12352

[16] Conteh C. Strategic inter organizational cooperation in complex environments. Public Management Review. 2013;15:501-521. DOI: 10.1080/14719037.2012.674424

[17] Gazley B. Good governance practices in professional associations for public employees: Evidence of a public service ethos? Public Administration Review. 2014;74:736-747. DOI: 10.1111/puar.12264

[18] Scott TA, Thomas CW. Unpacking the collaborative toolbox: Why and when do public managers choose collaborative governance strategies? The Policy Studies Journal. 2017;45:191-214. DOI: 10.1111/psj.12162

[19] Siddiki SN, Kim J, Leach WD. Diversity, trust, and social learning in collaborative governance. Public Administration Review. 2017;77:863-874. DOI: 10.1111/puar.12800

[20] Kim Y, Darnall N. Business as a collaborative partner: Understanding firms' sociopolitical support for policy formation. Public Administration Review. 2016;76:326-337. DOI: 10.1111/puar.12463

[21] Ulibarri N, Scott TA. Linking network structure to collaborative governance. Journal of Public Administration Research and Theory. 2017;27:163-181. DOI: 10.1093/jopart/ muw041

[22] Amsler LB. Collaborative governance: Integrating management, politics, and law. Public Administration Review. 2016;76:700-711. DOI: 10.1111/puar.12605

[23] Reuer J, Devarakonda SV. Mechanisms of hybrid governance: Administrative committees in non-equity alliances. Academy of Management Journal. 2016;59:510-533. DOI: 10.5465/amj.2012.0098 